\title{
Proximate and fatty acid composition of the liver of cultured Asian redtail catfish (Hemibagrus nemurus) and African catfish (Clarias gariepinus).
}

\begin{abstract}
Catfish species are popular fish group consumed in Malaysia. African catfish, Clarias gariepinus and Asian redtail catfish, Hemibagrus nemurus are two of these catfish species. Unfortunately, some parts of these fish are removed during processing. This includes the liver which contained considerable amount of extractable lipid with both monounsaturated and polyunsaturated fatty acids. The fish samples were purchased and transported in ice box to the laboratory. Liver was extracted and analyzed for crude protein, crude lipid, moisture, ash, carbohydrate contents and fatty acid composition. Results were compared between male and female C. gariepinus and $\mathrm{H}$. nemurus. Liver of female $\mathrm{H}$. nemurus contained the highest amount of ash, crude lipid and carbohydrate and the lowest amount of moisture. Male $\mathrm{H}$. nemurus had the lowest amount of protein, ash and crude lipid content. Moisture was found to be the highest in male $\mathrm{C}$. gariepinus. The main fatty acid content of Asian redtail catfish and African catfish liver were C12:0, C14:0, C15:0, C16:0, C16:1, C17:0, C18:0, C18:1n-9, C182n-6, C183n-3, C204n-6, C24:1, C205n-3, C225n-3, C226n-3. The most abundant fatty acids in both species were oleic acid (18:1n-9) and palmitic acid (16:0). In conclusion, this study showed that $\mathrm{H}$. nemurus and $\mathrm{C}$. gariepinus, are two valuable source of protein and polyunsaturated fatty acid.
\end{abstract}

Keyword: Fatty acid; Liver; Proximate; Hemibagrus nemurus; Clarias gariepinus. 